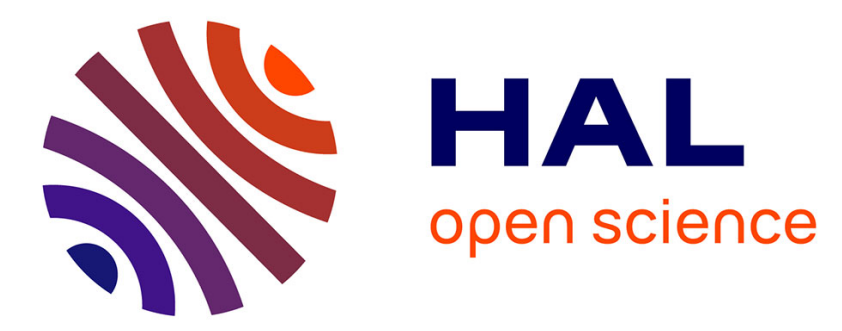

\title{
Sustainability Strategies in Industrial Practice
}

\author{
Silje Helene Aschehoug, Kjersti Øverbø Schulte
}

\section{To cite this version:}

Silje Helene Aschehoug, Kjersti Øverbø Schulte. Sustainability Strategies in Industrial Practice. IFIP International Conference on Advances in Production Management Systems (APMS), Sep 2017, Hamburg, Germany. pp.358-365, 10.1007/978-3-319-66926-7_41 . hal-01707251

\section{HAL Id: hal-01707251 \\ https://hal.inria.fr/hal-01707251}

Submitted on 12 Feb 2018

HAL is a multi-disciplinary open access archive for the deposit and dissemination of scientific research documents, whether they are published or not. The documents may come from teaching and research institutions in France or abroad, or from public or private research centers.
L'archive ouverte pluridisciplinaire $\mathbf{H A L}$, est destinée au dépôt et à la diffusion de documents scientifiques de niveau recherche, publiés ou non, émanant des établissements d'enseignement et de recherche français ou étrangers, des laboratoires publics ou privés. 


\title{
Sustainability Strategies in Industrial Practice
}

\author{
Silje Helene Aschehoug ${ }^{1}$, Kjersti Øverbø Schulte ${ }^{1}$ \\ ${ }^{1}$ SINTEF Raufoss Manufacturing, Raufoss/Trondheim, Norway \\ Silje.aschehoug@sintef.no, kjersti.schulte@sintef.no
}

\begin{abstract}
Sustainable product development (SPD) is a prerequsite to meet United Nations sustainable development goals (SDG). Manufacturing companies take on different stratiegies and ambitions in their sustainability approach. In a case study with four manufacturing companies; two automotive suppliers and two furniture companies, it is shed light on various strategies and practices for sustainability in industrial practice. The furniture companies have sustainability as a foundation for their business strategy and every day activities. On the other hand, the automotive suppliers obey regulations and their customers' demands. One reason for different approaches is the companies place in the value chain. A company with the product focal brand is more likely to gain from sustainability strategies and actions.
\end{abstract}

Keywords: Sustainability $\cdot$ Strategies $\cdot$ Manufacturing $\cdot$ Industry.

\section{Introduction}

For companies competing in the global market place, there is no longer a debate on whether one should consider the social and environmental impacts their activities and products have on external stakeholders. The interesting question now is how to integrate sustainability considerations and actions into day-to-day decision-making and strategic priorities. However, sustainability improvements must compete for attention in organizations that are also concerned with adapting new materials and technologies, increasing brand value, fulfilling user demands, or designing products with new meanings [1].

The principle of sustainable development was first introduced by the Brundtland Commission in 1987 as "development that meets the needs of the present without compromising the ability for future generations to meet their own needs" [2]. Today, sustainability is most commonly considered to have three dimensions, the economic, the social and the environmental, often referred to as the "triple bottom line" (TBL). Sustainable solutions are "products, services, hybrids or system changes that minimize negative and maximize positive sustainable impacts - economic, environmental, social and ethical - throughout and beyond the life-cycle of existing products and solutions, while fulfilling acceptable societal demands and needs" [3].

There is a large difference between companies and industries with regard to sustainability strategies. Based on Willard (2005), Hallstedt et al. (2010), summarized these strategies into five groups [4]: 1) Pre-compliance - ignoring sustainability and

adfa, p. 1, 2011.

(C) Springer-Verlag Berlin Heidelberg 2011 
opposing relating regulations, 2) Compliance - obeying laws and regulations on labor, environment, health and safety, 3) Beyond Compliance - recognizing opportunity to capitalize on resource efficiency and reduction of waste, however, sustainability is not integrated into core businesses, 4) Integrated Strategy - sustainability is integrated into company vision and strategy to be more successful than competitors, and 5) Purpose and passion which is more like a special type of companies, with a mission to save the world.

This article shed light on this issue by comparing four leading manufacturers and investigating how far they have come towards integrating sustainability strategies into daily business activities. The presented work builds upon and elaborates on the main author's previously published research from the Norwegian industry. The case study is limited to the social and environmental aspects of the sustainability notion. Hence, this article investigates the following research questions more in depth: What types of sustainability strategies linked to sustainable product development (SPD) are currenly used in the manufacturing industry? Which differences exist between industrial sectors?

\section{$2 \quad$ Background Studies}

Drivers for motivating or "pushing" companies to become more sustainable have been widely addressed by researchers over the past years, linking companies' overall sustainability performance to sustainable product development, as one cannot exist without the other. Legitimacy, competitiveness and social responsibility are categories for motivating companies into more sustainable actions [5, 6].

Legitimacy concerns complying with legislation and requirements from local authorities, national government, but also from international protocols and directives from the European Committee (EC) [6]. These directives are mandatory and are most commonly adopted and transposed into national legislation [7]. For manufacturing companies, the product-oriented environmental policies are particularly relevant. These include the Waste Electronics and Electrical Equipment (WEEE) Directive, the End of Live Vehicle (ELV) Directive, the Energy-Using Products (EuP) Directive, and the Restriction of the Use of Certain Hazardous Substances (RoHS) Directive. Such directives are expected to have growing impacts on industries in the years to come, both on products and processes [6]. The extended producer responsibility (EPR) principle is also expected to play a similar role. The purpose is to promote life cycle environmental improvements and to reduce pollution including resource and energy use. The EPR principle extends the responsibility of the producer to other parts of the life cycle, especially the product's end-of-life (EOL) phase [8].

Legitimacy also goes beyond mere complying with rules and regulations. It also includes a wider set of actions like audits, committee work and developing networks with local communities to provide a "license to operate" [6]. Such networks and committees involve both internal stakeholders within a company, but also relevant external stakeholders. Relevant internal stakeholder groups are management, employees, and labor unions. External stakeholders within this context are financial institu- 
tions, Non-Governmental-Organizations (NGOs), media, government, competitors, customers, suppliers, industry associations, and academia [9]. Different approaches have been suggested by researchers for useful stakeholder interaction on different levels between companies and its external environment. NGOs may for instance be engaged in ad hoc or long-term collaboration with companies, for example cocreating sustainable products with companies. In some instances, they may have the power to create market demands for sustainable products and thus foster sustainable consumption by linking consumer and company sustainability objectives closer to product development [10].

Competition concerns how sustainable strategies and actions may improve companies' competitiveness instead of being a cost factor. A recent literature study of the correlation between environmental and economical performance indicates that companies with a proactive strategy towards sustainability are likely to have economic benefits. On the other hand, reactive companies acting purely on enforced laws and regulations, are likely to experience additional cost and expenses related to sustainability strategies and actions [11]. A previous study also claims that larger environmental improvements following environmental investments are associated with expectations of higher financial gains [12]. Competitive benefits highlighted in literature for sustainable companies include, but not limited to: increased resource efficiency, increased return on investments, product differentiation, increased sales, improved image and development of new markets [6]. There is also a growing awareness among public agencies and large institutions who have developed guidelines for big volume purchases and for environmentally responsible public procurement, giving preferences to environmentally friendly products, and creating markets for environmentally benign products [8]. Hence, being a first mover may provide companies with a competitive advantage.

Activities upstream or downstream of the company's own production sites are important for the products' sustainability impact. Sustainable supply chain management (SSCM) have advantages like increased sales, more satisfied customers, smoother supply systems, and reduced costs [13, 14]. Involving suppliers in product development may additionally reduce time to market and improve product quality [15], however, supplier development and training may be required before the focal firm can offer more sustainable products $[13,16]$.

Stakeholder interaction may also contribute to a competitive advantage. Participatory design", "co-design", and "design for all" are design movements that actively involves the end user or consumer as a resource in the design process [18]. The main purpose of involving end users it to understand their needs and behavior. Additionally it is a way for the company of connecting customers closer to a company and creating brand loyalty.

In some industrial areas, eco-labels, certification and standards may give a competitive advantage. The ISO 14000-standards for instance, are based on guidelines and principles, in which some are third party verified product labels for environmental excellence, some are based on self declarations (green claims), and the third type is based on product environmental declarations with quantified product life cycle data. Eco-labels and sustainability related labels include the Nordic Council White Swan, 
German Blue Angel, EU Flower, Fair Trade, and the Forest Stewardship to mention a few. These labels make sustainable products easily recognizable for the customer [6, 17].

Social responsibility as a motivation to take on sustainability strategies and actions is the third motivational category for companies [5], and is highlighted as an important strategy for the UNs SDG. This category embraces corporate social responsibility (CSR) and ethical responsibility, both concerning manufacturing and product, but also in the wider value chain. Important issues include, but not limited to, adherence to human rights principles, code of conduct, work conditions, employment in developing countries, ethical marketing, bribery, honesty and trust in business relations. That is, the strategies the company adhere to, and the action to operationalize them [17].

\section{Research Design}

To answer the research questions a comparative case study was conducted. Selecting an appropriate sample is important in case study research [19]. The first two companies, AutoA and AutoB were chosen based on literal replication, based on similar business contexts. Both are direct suppliers to original equipment manufacturers (OEM) in the global automotive industry and have co-located manufacturing plants and in-house product development departments. AutoA operates within the segment of commercial vehicle systems and produces fluid transfer systems worldwide to medium and heavy commercial vehicles. AutoB is a leading supplier of engineered surface-treated interior and exterior plastic components.

The other two companies in the study were chosen based on theoretical replication and belong to the Norwegian furniture manufacturing industry. Their business context is entirely different from the automotive suppliers'. They sell their products directly to consumers via retailers. CompA and CompB have co-located manufacturing plants and in-house product development departments. CompA is an international firm which develops and manufactures premium brand office chairs, conference furniture and cafeteria furniture for private and public office environments. CompB is an international firm that develops and produces premium brand recliners, sofas, loveseats, and mattresses.

During the case study, assessments, observations, semi-structured (group) interviews, and reading of company documentation were performed to gain understanding of company performance on sustainability strategies related to sustainable product development. Product designers, engineers, including environmental managers, purchasing managers and development managers were interviewed. The collected data was analysed in data displays with the aim to identify current sustainability strategies and practices in the companies linked to sustainable product development. 


\section{$4 \quad$ Results and Discussion}

Comparison of four manufacturing companies demonstrates significant differences with regard to sustainability strategies and industrial practice. Table 1 reports the overall findings linked to motivational categories for the companies.

Table 1. Industrial practice on sustainability strategies and performance

\begin{tabular}{|c|c|c|c|c|c|}
\hline Motivation & $\begin{array}{l}\text { Environmental and social } \\
\text { sustainability strategies }\end{array}$ & $\underset{\mathrm{A}}{\text { Comp }}$ & $\begin{array}{c}\text { Comp } \\
\text { B }\end{array}$ & $\begin{array}{c}\text { Auto } \\
\text { A }\end{array}$ & $\begin{array}{c}\text { Auto } \\
\text { B }\end{array}$ \\
\hline \multirow[t]{5}{*}{ Legitimacy } & Compliance with regulations & $\mathrm{X}$ & $\mathrm{X}$ & $\mathrm{X}$ & $\mathrm{X}$ \\
\hline & $\begin{array}{l}\text { Sustainability clearly defined in } \\
\text { strategies and policies }\end{array}$ & $\mathrm{X}$ & $\mathrm{X}$ & & \\
\hline & Eco-branding of products & $\mathrm{X}$ & $\mathrm{X}$ & & \\
\hline & $\begin{array}{l}\text { Stakeholder (external) interaction } \\
\text { in i.e. product development }\end{array}$ & $\mathrm{X}$ & $\mathrm{X}$ & & \\
\hline & $\begin{array}{l}\text { Internal stakeholder interaction } \\
\text { (educational programs, task forces } \\
\text { etc.) }\end{array}$ & $\mathrm{X}$ & $\mathrm{X}$ & $\mathrm{X}$ & $\mathrm{X}$ \\
\hline & & & & & \\
\hline \multirow[t]{4}{*}{ Competition } & $\begin{array}{l}\text { Environmental management sys- } \\
\text { tems (ISO 14001, EMAS etc.) }\end{array}$ & $\mathrm{X}$ & $\mathrm{X}$ & $\mathrm{X}$ & $\mathrm{X}$ \\
\hline & SPD tools implemented & $\mathrm{X}$ & & & \\
\hline & Product sustainability labels & $\mathrm{X}$ & & & \\
\hline & $\begin{array}{l}\text { Sustainability focused supplier } \\
\text { development programs }\end{array}$ & $\mathrm{X}$ & $(\mathrm{X})$ & $(\mathrm{X})$ & $(\mathrm{X})$ \\
\hline \multirow[t]{3}{*}{$\begin{array}{l}\text { Social } \\
\text { Responsibility }\end{array}$} & \begin{tabular}{|l|} 
CSR strategies, standards and ac- \\
tions (SA 8000, AA 10000, etc.)
\end{tabular} & $\mathrm{X}$ & & & \\
\hline & $\begin{array}{l}\text { Philanthropy activities, community } \\
\text { engagement, sponsoring }\end{array}$ & (X) & $\mathrm{X}$ & & \\
\hline & Company ethical guidelines & $\mathrm{X}$ & $\mathrm{X}$ & & \\
\hline
\end{tabular}

\subsection{Maturity level}

CompA may be regarded as industrial best practice among these companies. CompA is known far beyond its marked segment to take necessary actions to ensure environmental and social responsibility. The organization demonstrated a high maturity level on sustainability matters throughout the organization that goes beyond management level. CompA provided examples of changing product design, material choice or suppliers due to poor social, ethical or environmental performance of certain product parts. Based on Hallstedt et al. (2010) [4], CompA fits the "Integrated Strategy-level 
4" category, in which sustainability is integrated into all business activities from strategy, innovation, design and improved financial risk assessments.

Sectorwise, the study reveals predicted difference between the furniture sector and the automotive sector. In terms of integrated sustainability strategies [4], AutoA and AutoB are within the "Compliance-level 2" category with regard to environmental sustainability, obeying what they must, without recognizing opportunities and gains of doing more in the sustainability field. There seem to be fewer motivational factors to push these automotive suppliers into more sustainable actions. A plausible interpretation may be the companies' different places in the value chains. The automotive companies operate within a minimum compliance sector in the business-to-business (B2B) segment. The furniture companies on the other hand, operate in the businessto-consumer segment (B2C). Attention for negative or positive sustainability performance from consumers, media and NGOs is often given to the focal firm in a value chain; the brand itself or the brand owning company. Hence, brand owning companies downstream a value chain like the furniture companies, are more likely to be negatively exposed, and also more likely to receive financial returns on sustainability improvements.

Currently, the main drivers for improvements in AutoA are safety and quality, and lightweight interior for AutoB. Both companies reported that they would wait for customer requirements or governmental regulations before taking on more sustainability strategies and actions. The furniture companies on the other hand expressed a wish to be in the driver's seat in sustainability issues in order to capitalize on first mover advantages. Significant SPD investments had already been made, despite currently small markets for such products. These investments were mostly motivated by eco-efficiency strategies for financial gains for CompB. CompB therefore falls into the "Beyond Compliance -level 3" category [4].

\subsection{Management Commitment and Training as Supporting Practices}

Interestingly, all four companies reported management commitment to be the most important factor when working with sustainability issues. The accepted norm is based on what management do, not what they say, hence management must "walk the talk". Literature reports that employees are directly and indirectly affected by managerial attitudes and positions as motivators when it comes environmental pro-activity [20]. All four companies suggested that sustainability actions should be linked to economic performance and shareholder value as a way to keep long-term management attention.

Only CompA had designated and trained designers within SPD, and worked actively with various SPD tools to reduce negative social or environmental impacts. Many SPD tools are comprehensive, they require special training for correct use (e.g. LCA). This increases the threshold against using these tools. In addition to increasing the sustainability performance of a product, designers can also influence and encourage consumers towards more sustainable consumption by providing more sustainable product alternatives and by making such features visible and apparent [21]. Hence, SPD training will become more important in the future for companies that wish to enhance their product sustainability performance. 
Related to this issue is the overall sustainability competence level in a company, a prerequisite for sustainable actions. The need for a "sustainability champion" to help with competence was highlighted by all interviewees. CompA was the only one with a designated sustainability champion (environmental manager). However, the responsibility for sustainability changes in CompA remains within each management level.

Furthermore, CompA pointed out that working with sustainability issues goes beyond mere sustainability competence. Despite adequate training, they have observed that employees' personal motivation influence how they react and respond in day-today actions. Some employees search actively for relevant information and act upon it. Others are satisfied to fulfill minimum requirements. Employees in different functions and hierarchical levels have different backgrounds and experiences, and also different worldviews on sustainability. Consequently, organizations also needs to go beyond competence and training and work with motivational issues and culture.

Our case studies based on the framework of Willard (2005) and Hallstedt et al. (2010) [4], demonstrate companies with different levels of sustainability strategies. To operate on a higher level, environmental and social sustainability issues are embedded in the entire organization and demonstrating a broad motivational ground from legitimacy, competition and social responsibility.

\section{Conclusion}

Increasing global competition is forcing manufacturing companies to continuously improve their business with sustainable and innovative products. From the presented case research of four manufacturing companies, we have learned that companies adapt different sustainability strategies and actions dependent on their business context. Focal brand companies, and "first movers", may have the best financial gains from sustainability improvements. Best industrial practice in the current study include: sustainability clearly defined in company strategies and policies, product sustainability labelling, SPD tool implemented, sustainability focused supplier programs, adherence to CSR strategies and standards, philanthropy activities and different stakeholder interaction programs for both internal and external stakeholders.

This study indicates that in order to succeed with sustainability strategies and actions in industrial practice, organizations need more than competence and training programs for designers. Management commitment, task forces as well as "sustainability champions" are important pieces in the overall "puzzle”. In addition, companies need to work with personal motivational issues and culture, because employees' personal motivation influence how they react and respond in day-to-day actions.

Although much research has been conducted on sustainable companies, little focus has been directed towards identifying best industrial practice for other companies to learn from. To enhance the results more research is needed from multiple organizations trying to implement sustainability strategies and actions.

Acknowledgements. This research is supported by the Research Council of Norway. 


\section{References}

1. Verganti R (2009) Design-driven innovation. Changing the rules of competition by radically innovating what things mean. Harvard Business Press, Boston, Massachusetts

2. UNEP (1987) Our Common Future. Report of the World Commission on Environment and Development, Oxford Press.

3. Charter M, Tischner U. (2001) Sustainable solutions. Sheffield, UK: Greenleaf Publishing.

4. Hallstedt S, et al. (2010) An approach to assessing sustainability integration in strategic decision systems for product development. J of Cleaner Production 18(8):703-712.

5. Bansal P, Roth K (2000) Why Companies Go Green: A Model of Ecological Responsiveness. Academy of Management Journal 43(4):717-736.

6. Albino V, Balice A, Maria R (2009) Environmental strategies and green product development: an overview on sustainability-driven companies. Business Strategy and the Environment 18(2):83.

7. Angerer G, Nordbeck R, Sartorius C (2008) Impacts on industry of Europe's emerging chemicals policy REACh. J of Environmental Management 86(4):636-647.

8. Li L, Geiser K (2005) Environmentally responsible public procurement (ERPP) and its implications for integrated product policy (IPP). J of Cleaner Production 13(7):705-715.

9. Donaldson T, Preston LE (1995) The Stakeholder Theory of the Corporation: Concepts, Evidence, and Implications. The Academy of Management Review 20(1): 65-91.

10. Kong N, et al. (2002) Moving Business/Industry Towards Sustainable Consumption: The Role of NGOs. European Management Journal 20(2):109-127.

11. Trumpp C, Guenther T (2017) Too Little or too much? Exploring U-shaped Relationships between Corporate Environmental Performance and Corporate Financial Performance. Business Strategy and the Environment 26:49-68.

12. Plaza-Ubeda JA, et al. (2009) The 'win-win' paradigm and stakeholder integration. Business Strategy and the Environment 18(8):487.

13. Sharfman MPM, Shaft TMT, Anex RPR (2009) The road to cooperative supply-chain environmental management: trust and uncertainty among pro-active firms. Business Strategy and the Environment, 18(1):1.

14. Handfield R, Sroufe R, Walton S (2005) Integrating environmental management and supply chain strategies. Business Strategy and the Environment 14(1):1

15. Johansson G, Magnusson T (2006) Organising for environmental considerations in complex product development projects: implications from introducing a "Green" sub-project. J of Cleaner Production 14(15-16): 1368-1376.

16. Seuring S, Müller M (2008) From a literature review to a conceptual framework for sustainable supply chain management. J of Cleaner Production 16(15):1699-1710.

17. Waage SA, et al. (2005) Fitting together the building blocks for sustainability: a revised model for integrating ecological, social, and financial factors into business decisionmaking. J of Cleaner Production 13(12):1145-1163.

18. Sanders L (2008) An evolving map of design practice and design research. Interactions 15(6):13-17.

19. Yin RK (2009) Case Study Research, Design and Methods, $4^{\text {th }}$ ed. Applied Social Research Methods Series, Vol 5, D.J.R. Leonaard Bickman (ed). Sage Publications Inc.

20. González-Benito J, González-Benito Ó (2006) A review of determinant factors of environmental proactivity. Business Strategy and the Environment 15(2):87-102.

21. Marchand A, Walker S (2008) Product development and responsible consumption: designing alternatives for sustainable lifestyles. J of Cleaner Production 16(11):1163-1169. 